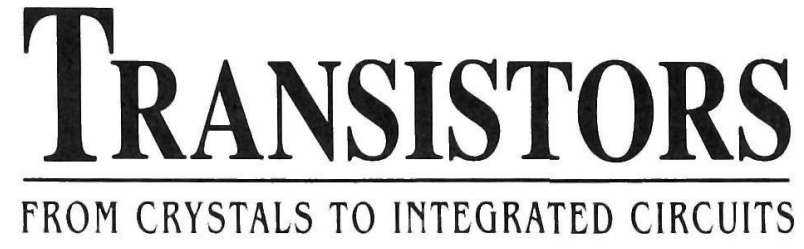




\section{This page is intentionally left blank}




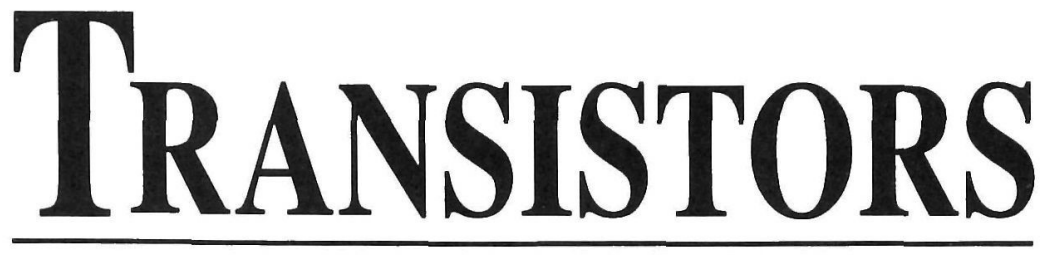

FROM CRYSTALS TO INTEGRATED CIRCUITS

\section{Levinshtein \& G Simin}

IOFFE Institute of Russian Academy of Sciences, Russia

Translated by

Minna M Perelman 


\section{Published by}

World Scientific Publishing Co. Pte. Ltd.

P O Box 128, Farrer Road, Singapore 912805

USA office: Suite 1B, 1060 Main Street, River Edge, NJ 07661

UK office: 57 Shelton Street, Covent Garden, London WC2H 9HE

\section{British Library Cataloguing-in-Publication Data}

A catalogue record for this book is available from the British Library.

\section{TRANSISTORS. FROM CRYSTALS TO INTEGRATED CIRCUITS}

Copyright () 1998 by World Scientific Publishing Co. Pte. Ltd.

All rights reserved. This book, or parts thereof, may not be reproduced in any form or by any means, electronic or mechanical, including photocopying, recording or any information storage and retrieval system now known or to be invented, without written permission from the Publisher.

For photocopying of material in this volume, please pay a copying fee through the Copyright Clearance Center, Inc., 222 Rosewood Drive, Danvers, MA 01923, USA. In this case permission to photocopy is not required from the publisher.

ISBN 981-02-2743-4

This book is printed on acid-free paper.

Printed in Singapore by Uto-Print 


\section{To my friends. M.L. To my sons Kirill and Misha. G.S.}




\section{This page is intentionally left blank}




\section{Preface}

This book will tell you about the design and work of transistors and diodes - the most important semiconductor devices.

A few years ago this book was published in Russian in Moscow and about 140000 copies of it were sold in the former USSR.

We found that the majority of those who had bought it were senior grade pupils interested in semiconductors, those who thought about their future careers, those who were considering semiconductor physics, materials science, electrical engineering or semiconductor processing as their future profession, though they didn't quite realize what semiconductor electronics actually is.

Many of our readers were undergraduates (mainly freshmen). We were glad to know that the book had proved to be useful supplementary reading, facilitating their learning process.

We did not expect it and were happy to know that graduates and postgraduates were also interested in the book. Some of our readers have degrees (B.Sc., or M.Sc., some are getting PhDs), and yet they wrote to tell us that what had seemed to them most complicated and perceivable only by means of differential equations and computer simulation, became quite simple and understandable after they had read the book. Semiconductor designers and technologists were also interested in the book. They found some new ideas and unexpected approaches in the book.

Several professors, who deliver lectures in semiconductor physics and semiconductor devices, have written to us saying that they think it is expedient to recommend the book to their students as supplementary reading.

Thus, the book has proved to be interesting to quite a lot of people whose range and levels of knowledge are very different.

We are thankful to our friends and colleagues: Michael I. Dyakonov, Professor, Principal Scientist of the Ioffe Institute, St. Petersburg, Russia; Boris I. Shklovskii, Professor, University of Minnesota, USA; Igor M. Filanovskii, Professor, University of Alberta, Canada for their help in the work featured in this book. We are grateful to our wives Larisa and Marianna for their 
viii Preface

patience, understanding and friendly support. We want to thank our children: Dina Levinshtein and Misha and Kirill Simin for their love which helped a lot. We are grateful to Minna M. Perelman, the translator of this book, and also of our book "Getting to Know Semiconductors", published by World Scientific in 1992. Her energy and courage inspired our work. Our special thanks are also extended to Marianna A. Simin: her funny pictures created an easy and friendly atmosphere.

M. Levinshtein

G. Simin 


\section{Contents}

Preface vii

Introduction 1

Part I. Semiconductors 3

$\begin{array}{ll}\text { Chapter 1. The Main Properties of Semiconductors } & 7\end{array}$

$\begin{array}{ll}1.1 \text { Intrinsic Semiconductors } & 7\end{array}$

1.1.1 "Free electrons" in crystal 8

1.1.2 Holes 9

$\begin{array}{ll}1.1 .3 \text { Generation and recombination } & 10\end{array}$

Thermal generation 11

Electron-hole recombination $\quad 12$

Intrinsic concentration $\quad 13$

$\begin{array}{ll}\text { The simplest band diagrams } & 14\end{array}$

$\begin{array}{ll}1.2 \text { Impurity Semiconductors } & 16\end{array}$

$\begin{array}{ll}\text { 1.2.1 Donor impurity } & 17\end{array}$

$\begin{array}{ll}1.2 .2 \text { Acceptor impurity } & 19\end{array}$

1.2.3 The temperature dependence of the carrier concentration 21

$\begin{array}{ll}1.2 .4 \text { Minority carriers } & 23\end{array}$

1.2.5 Band diagrams $\quad 24$

Compensation 26

1.3 Deep Levels 28

$\begin{array}{ll}\text { 1.3.1 Compensation by deep levels } & 29\end{array}$

1.3.2 Generation through deep levels 31

1.3.3 Recombination through deep levels 34

1.4 Summary 36

Chapter 2. Motion of Electrons and Holes inside the Crystal $\quad 39$

2.1 Thermal Motion 40

2.1.1 Energy distribution of electrons $\quad 40$

2.1.2 Energy distribution of holes $\quad 42$ 
2.2 Motion in the Electric Field 48

2.2 .1 "Hot" electrons $\quad 50$

2.2.2 Band diagrams $\quad 51$

2.3 Diffusion $\quad 55$

2.3.1 Diffusion coefficient $\quad 57$

2.3.2 Diffusion current $\quad 59$

2.3.3 Diffusion length 60

2.4 Summary 64

Part II. Barriers \& Junctions $\quad 65$

$\begin{array}{ll}\text { Chapter 3. The Barrier on the Crystal Boundary } & 67\end{array}$

3.1 Work Function 69

3.1.1 Come back, return, I call you back! $\quad 70$

$\begin{array}{ll}3.1 .2 \text { Double charged (dipole) layer } & 70\end{array}$

3.1.3 How to define the work function $\quad 72$

Red boundary of the extrinsic photoelectric effect 72

Thermoionic emission $\quad 73$

3.1.4 What work function is equal to 74

Work function in metals 74

Work function in semiconductors $\quad 74$

$\begin{array}{ll}3.2 \text { Surface States } & 78\end{array}$

3.3 Bending Bands, Surface Potential $\quad 80$

3.4 Summary 84

Chapter 4. The Main Parameters of Potential Barriers 85

4.1 How the Electric Field Penetrates into a Metal, Dielectric and Semiconductor $\quad 86$

4.1.1 Why the electric field practically does not penetrate into a metal $\quad 86$

4.1.2 How the electric field penetrates into a dielectric 88

4.1.3 In what way and how deep the electric field penetrates into a semiconductor 90

4.2 Field Dependence on the Coordinate $\quad 92$

4.3 Poisson's Equation 94

4.4 A Few Words about Accumulation Layers 97

$\begin{array}{ll}4.5 \text { Summary } & 98\end{array}$ 
Chapter 5. $p$ - $n$ Junction $\quad 99$

5.1 Ways of Obtaining $p-n$ Junctions 99

$\begin{array}{ll}5.1 .1 \text { Alloying } & 101\end{array}$

5.1.2 Diffusion 103

5.1.3 Ion implantation 105

$\begin{array}{ll}5.2 \text { Barrier on the Boundary } & 108\end{array}$

5.2.1 The height of the barrier $\quad 111$

5.2.2 Depletion layer. Width of the barrier 113

$\begin{array}{ll}5.2 .3 \text { Wonderful equilibrium } & 117\end{array}$

5.2.4 The reverse bias 124

Height and shape of the barrier $\quad 126$

$\begin{array}{ll}\text { Reverse current } & 127\end{array}$

Barrier capacity 130

5.2.5 The forward bias $\quad 133$

The height of the barrier 133

Forward current 133

Injection 137

5.3 Summary 143

Chapter 6. Diodes with the $p$ - $n$ Junctions 145

$\begin{array}{ll}6.1 \text { Photodiodes } & 145\end{array}$

$\begin{array}{ll}6.2 \text { Variable Capacitors } & 149\end{array}$

6.3 Light-Emitted Diodes 151

6.4 Solar Cells 154

$\begin{array}{ll}6.5 \text { Rectifier Diodes } & 159\end{array}$

6.6 Summary 165

$\begin{array}{ll}\text { Part III. Transistors } & 167\end{array}$

$\begin{array}{lr}\text { Chapter 7. Bipolar Transistors } & 169\end{array}$

7.1 Principle of Operation of a Bipolar Transistor 170

7.1.1 Current amplification 172

7.1.2 Parable about what is main and what is minute $\quad 175$

7.1.3 Speed of response of the transistor 176

7.2 Some Words about the Types and Manufacturing of Bipolar Transistors 
7.3 The Simplest Transistor Circuits

7.4 Summary

Chapter 8. Field Effect Transistors

8.1 The Beginning

8.1.1 The main idea

8.1.2 Simple estimations

8.1.3 Old acquaintances

8.2 Maturity and Flourishing

8.2.1 JFET (p-n-junction field effect transistor)

8.2.2 Fortune favours the brave. MOSFET

8.3 Epitaxy

8.4 A Few Important Details

8.5 The Work of the FETs in Actual Regimes

8.5.1 The main parameters of FETs

Transconductance

Speed of response

8.6 FET as an Element of Electronic Circuits

8.7 Summary

Chapter 9. Transistors and Life

9.1 The First King

9.2 Ugly Duckling

9.3 Long Live the New King! 231

9.4 The King... Disappears. Long Live the New King!

9.5 Claimants to the Throne

Three-dimensional intergrated circuits

Semiconductor elements of the optical computers

Bioelectronics 